\title{
TOTAL NONDIALYZABLE SOLIDS (TNDS) IN HUMAN URINE. IV. ELECTROPHORETIC PROPERTIES OF RS-1 SUBFRACTION *
}

\author{
By WILLIAM H. BOYCE AND J. STANTON KING, JR. \\ (From the Departments of Urology and Biochemistry, The Bowman Gray School of Medicine \\ of Wake Forest College, Winston-Salem, N.C.)
}

(Submitted for publication March 30, 1959; accepted May 14, 1959)

The nonultrafiltrable, veronal soluble components of the total nondialyzable solids (TNDS) of normal human urine have been designated as the RS-1 fraction (1). Separation of RS-1 into three subfractions by a modification of Cohn's Method 10 for fractionation of human plasma has been reported (2). The RS-1 and subfractions RS-1A (Cohn I, II and III), RS-1B (Cohn IV and V) and RS-1C (Cohn VI) have been subjected to boundary electrophoresis at $\mathrm{pH} 8.6$ and 4.5. The comparison of concentration gradients appearing in these several fractions of urinary proteins and in normal human serum provides the subject matter of the present report.

\section{MATERIALS AND METHODS}

The human subjects and methods of collection of 24 hour urine specimens were the same as previously reported (1). The RS-1 fraction of 72 hour urine collections from each subject was recovered in the lyophilized state as previously described. Such a collection contained approximately $150 \mathrm{mg}$. of dry RS-1 solids.

Veronal buffer was prepared as previously described (2). The acetate buffer was prepared by dilution of 20 ml. of $2 \mathrm{~N}$ sodium acetate, $11.5 \mathrm{ml}$. of $3.5 \mathrm{M}$ acetic acid and $32 \mathrm{ml}$. of $5 \mathrm{M}$ sodium chloride to a volume of $2 \mathrm{~L}$. with distilled water. This buffer at $1^{\circ} \mathrm{C}$. had a conductivity of $5.12( \pm 0.05) \times 10^{-3}$ mho and a $\mathrm{pH}$ of 4.5 .

Electrophoresis. The moving boundary electrophoresis was done in a Beckman-Spinco model $\mathrm{H}$ electrophoresisdiffusion apparatus. The same standard long-channel $(9.2 \mathrm{~cm}$.) analytical cell of $11 \mathrm{ml}$. capacity was used in all experiments to minimize variation in calculations of mobility. A cadmium-mercury light source (General Electric No. H-100 F4) and the Philpot diagonal diaphragm-cylindrical lens optical system were used. Photographs were made on glass plates using a No. 29 Wratten contrast filter (dominant transmission $644 \mu$ ) for the Eastman high resolution spectroscopic plates (emulsion No. 514, 251), and a No. 15 Wratten contrast filter (domi-

* Supported by Public Health Service Grant A-259, National Institutes of Health, and by grants from the Mary Reynolds Babcock Foundation and The American Urological Research Foundation. nant transmission $546 \mu$ ) for the Eastman high resolution metallographic plates.

Mobilities of the concentration gradients were calculated in the usual manner, with the exception that the distance of migration was measured from the advancing margin of the ascending protein buffer gradient and from the trailing margin of the descending protein-buffer gradient of the initial boundaries. This deviation was made necessary by the exceedingly high color of the urinary proteins, which obscured the exact center of the initial protein-buffer boundaries in some instances. The percentage composition of the various concentration gradients was determined by planimetry of photographic enlargements of the patterns after the method of Longsworth and MacInnes (3).

Although more than 50 specimens of RS-1 have been studied electrophoretically in this laboratory, the present report is limited to the following experiments conducted specifically for collection of these data.

Eleven subjects, eight male and three female, submitted three consecutive 24 hour urine specimens, from which the RS-1 was recovered as the lyophilized solids (1). These solids (approximately $150 \mathrm{mg}$. dry weight) were taken up in $12 \mathrm{ml}$. of veronal buffer, dialyzed against buffer overnight, and subjected to electrophoresis at $1^{\circ} \mathrm{C}$. under a potential gradient of 5.6 volt $/ \mathrm{cm}$. for $14,400 \mathrm{sec}-$ onds. The patterns were photographed at one hour intervals and the protein solution recovered from the cell.

The recovered protein was dialyzed against repeated changes of acetate buffer until $\mathrm{pH}$ and conductivity studies indicated equilibrium had been reached (three to five buffer changes in 72 to 96 hours). A small sediment was recovered on centrifugation of the acetate-equilibrated proteins. This precipitate was readily soluble in $4 \mathrm{ml}$. of veronal buffer, and after equilibrium dialysis these proteins were then subjected to electrophoretic migration at $\mathrm{pH} 8.6$ in the $2 \mathrm{ml}$. microanalytical cell for $14,400 \mathrm{sec}-$ onds under a potential gradient of 6.45 volt $/ \mathrm{cm}$.

The ascending and descending boundaries of the supernate from the $\mathrm{pH} 4.5$ equilibrated RS-1 solids were brought to the midpoint of the center section of the $11 \mathrm{ml}$. analytical cell and electrophoretic migration conducted for 14,400 seconds under a potential gradient of $6.6 \mathrm{volt} / \mathrm{cm}$. Photographs were made at hourly intervals. The protein solution was then recovered from the cell, and in some instances then equilibrated with veronal buffer by dialysis, and subjected to a repeat electrophore- 


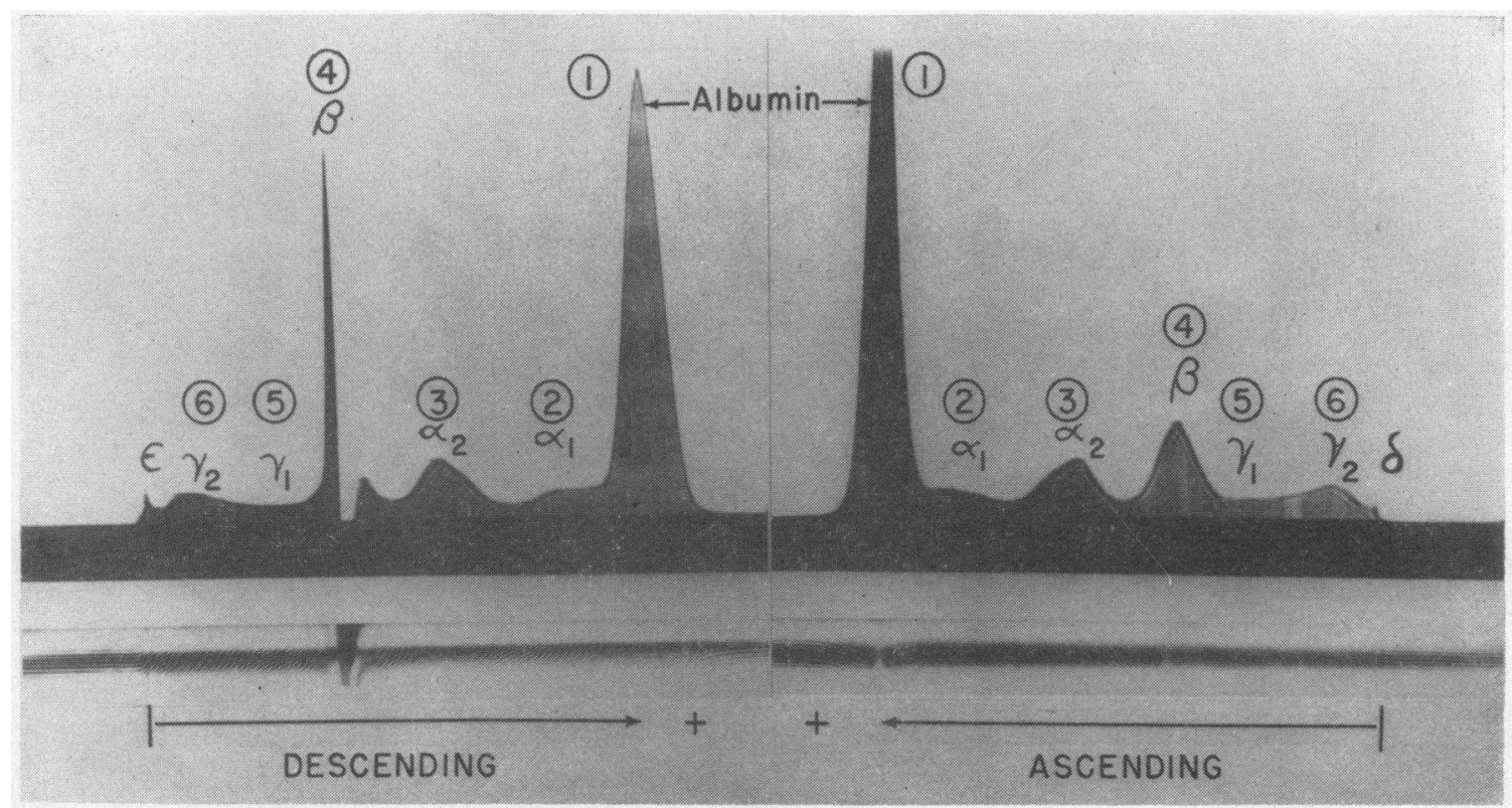

Fig. 1. Electrophoretic Concentration Gradients of Normal Human Serum

Separation in veronal buffer, ionic strength $0.1, \mathrm{pH} 8.6$, at $1^{\circ} \mathrm{C}$., under a potential gradient of 5.6 volt $/ \mathrm{cm}$. for 14,400 seconds. Concentration gradients are numbered in order of decreasing mobility toward the anode.

sis under the conditions described for veronal-buffered proteins above.

Three pools of RS-1 from urine collections from 12 subjects were recovered in the lyophilized state. The dry weights were determined and a 0.1 aliquot (approximately $180 \mathrm{mg}$.) was removed for electrophoresis at $\mathrm{pH}$ 8.6 and 4.5 as described for the individual RS-1 samples above. Each was then separated into fractions RS-1A

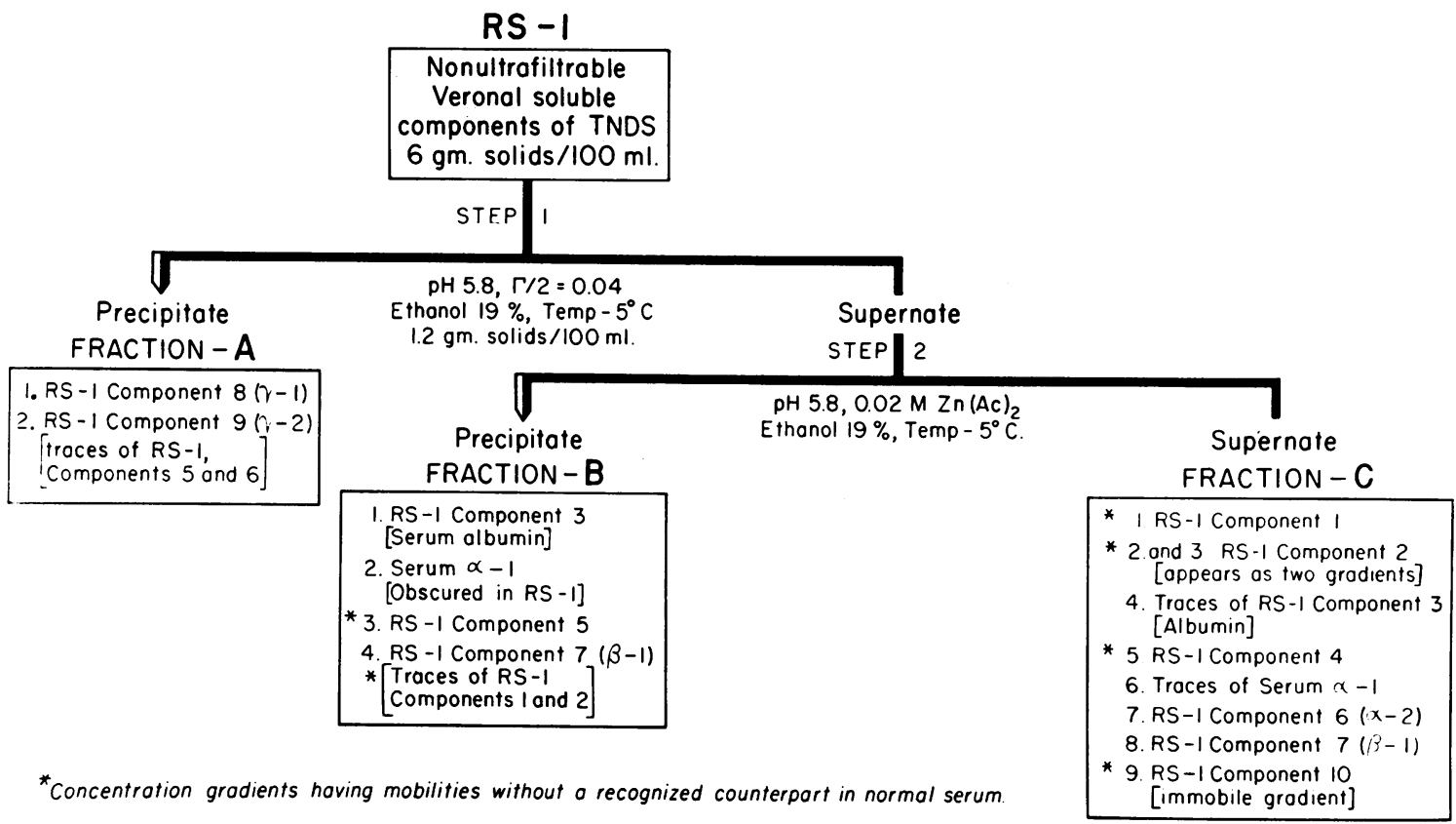

Fig. 2. Concentration Gradients Identified Electrophoretically at PH 8.6 in the Three Subractions of RS-1 SoLIDS 
(Cohn I, II and III), RS-1B (Cohn IV and V), and RS-1C (Cohn VI) by a modification of Cohn's Method 10 , as previously described.

The wet precipitates of RS-1A were taken up in 3.5 $\mathrm{ml}$. of veronal and equilibrated against the buffer by dialy- sis. Electrophoresis was then carried out in the $2 \mathrm{ml}$. microanalytical cell for 14,400 seconds under a potential gradient of 5.6 volt/seconds. This material was not studied electrophoretically at $\mathrm{pH} 4.5$, since practically all of the protein precipitated spontaneously during the equili-

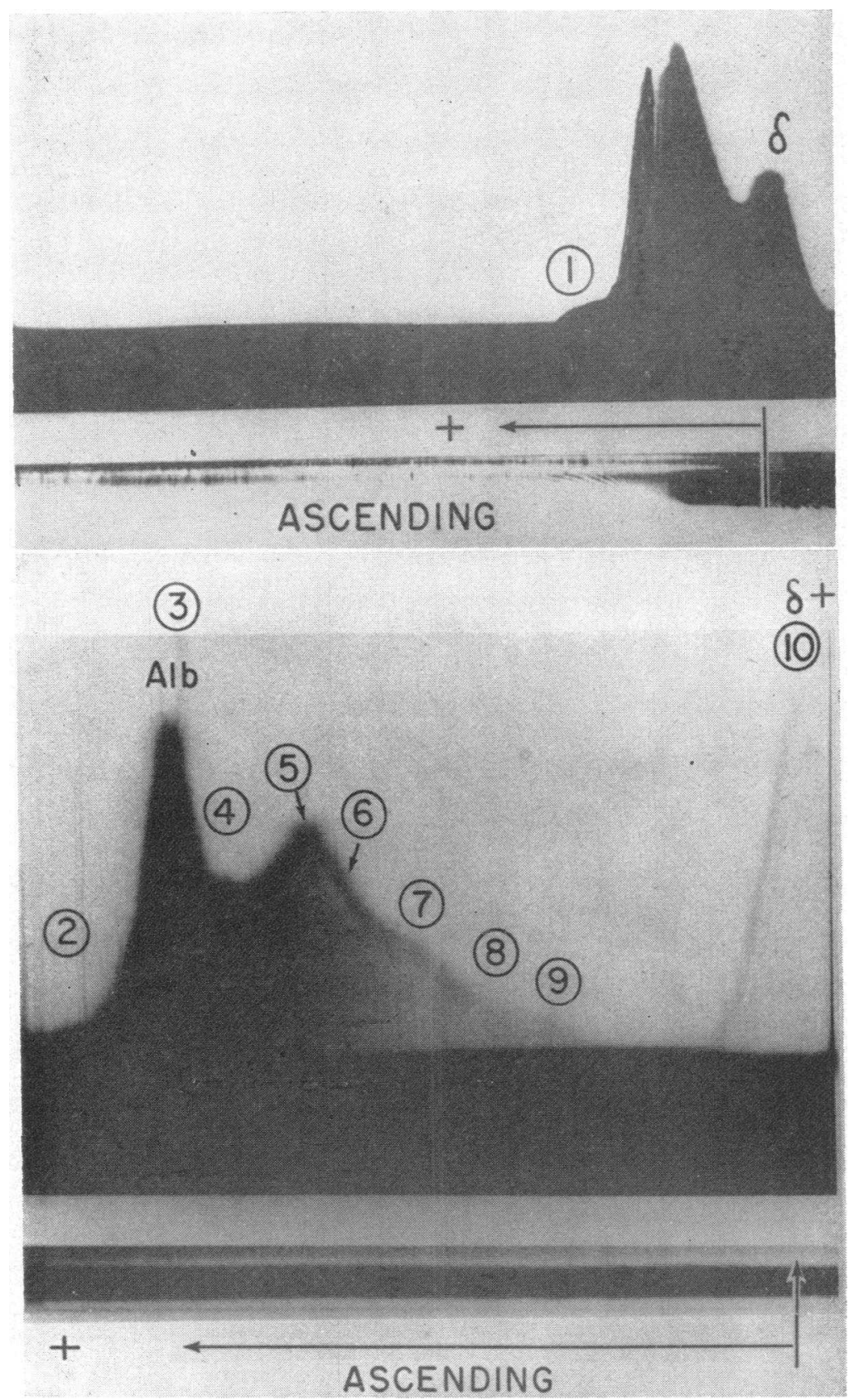

Fig. 3. Concentration Gradients of Pooled Total RS-1 Solids (Pool 14) Identified Electrophoretically

Separation in veronal buffer, ionic strength $0.1, \mathrm{pH} 8.6$, at $1^{\circ} \mathrm{C}$., under a potential gradient of $5.6 \mathrm{volt} / \mathrm{cm}$. (A) After migration for 3,600 seconds to demonstrate gradient 1; (B) after migration for 14,400 seconds (gradient 1 is beyond the optical range). 
bration dialysis with acetate buffer. This behavior was not altered by taking up the RS-1A precipitates in 15 $\mathrm{ml}$. of veronal and concentrating to a volume of $3.5 \mathrm{ml}$. by lyophilization. A similar fraction of plasma proteins (Cohn I, II and III) obtained by the same technique as RS-1A showed no significant precipitation on dialysis to $\mathrm{pH} 4.5$, but electrophoresis at $\mathrm{pH} 8.6$ indicated many more components than the urinary RS-1A. Commercial human gamma globulin was also soluble in the $\mathrm{pH} 4.5$ buffer at concentrations of 1 to 2 per cent.

The wet precipitates of RS-1B (Cohn IV and V) were taken up in veronal buffer sufficient to give a protein concentration of 1.3 to 1.5 per cent weight/volume. Electrophoresis at $\mathrm{pH} 8.6$ and 4.5 was done as described above. A precipitate obtained on centrifugation of the $\mathrm{pH} 4.5$ equilibrated $\mathrm{RS}-1 \mathrm{~B}$ was subjected to electrophoresis at $\mathrm{pH} 8.6$ as described for the whole RS-1 fraction.

The RS-1C (Cohn VI) components were recovered from the $260 \mathrm{ml}$. of filtrate by dialysis against distilled water and subsequent lyophilization. The dry solids were then suspended in veronal buffer to give a concentration of 1.5 per cent (weight/volume) and electrophoresis at $\mathrm{pH} 8.6$ and 4.5 was accomplished as above. No precipitate was obtained on centrifugation of the $\mathrm{pH} 4.5$ equilibrated RS-1C.

\section{RESULTS}

Veronal buffer, $p H$ 8.6.

The concentration gradients consistently identified in each fraction were numbered in order of decreasing mobility toward the anode. The method of numbering is illustrated with the familiar pattern of normal serum in Figure 1. A flow sheet of those gradients appearing in the various Cohn fractions at $\mathrm{pH} 8.6$ is presented in Figure 2. In veronal buffer at $\mathrm{pH} 8.6$, a total of 10 concentration gradients was consistently identified in RS-1 (Figure 3). The relative concentration (area) of each gradient was determined by planimetry (Table I). The relative concentrations of the various gradients were quite constant for the three pooled samples; seven of the 11 individual RS-1 samples were within the range of variation encountered in the pooled specimens. Four of the individual RS-1 samples were found to have variations in area in gradients 5, 6 and 10 which were greater than one standard deviation from these gradients of the pooled samples. Representative examples of the archetypal and variant electrophoretic patterns of individual samples of RS-1 are presented in Figure 4.

The mobility relations of these RS- 1 concentration gradients to those of normal serum under identical conditions of electrophoresis and mode of calculation are illustrated in Table II and Figures 5, 6 and 7. Note that the mobilities of serum components are approximately 10 per cent greater than those reported by Dole (4). This is due to the necessity of measuring distances of descending migration from the trailing margin of the initial protein buffer boundary, and possibly to slight mechanical variations in the optical systems and instruments.

RS-1 concentration gradient 1 was recognized as the " $x$ "-component by Rigas and Heller (5) (Figure 3A). Concentration gradients 1 and 2 were previously designated as fast components in this laboratory (6). These components appear in both RS-1B and RS-1C fractions but are more clearly delineated in RS-1C, in which they may be relatively more concentrated. The appearance of RS-1 gradient 2 as two gradients (RS-1C gradients 2 and 3 ) in fraction $C$ is not unexpected, since this gradient tended to spread in RS-1 and was relatively more concentrated in RS-1C.

Paper electrophoresis at $\mathrm{pH}$ 8.6, with commercial chondroitin sulfate as a control and aqueous toluidine blue $O$ for development, has suggested the presence of two major components showing $\gamma$-metachromasia in RS-1, and in both RS-1B and RS-1C fractions. The faster component had a mobility slightly less than commercial chondroitin sulfate and the second component was

TABLE I

Average percentage of $R S-1$ present in each concentration gradient on separation at pH 8.6, as determined planimetrically* from both ascending and descending patterns

\begin{tabular}{|c|c|c|c|c|c|c|c|c|c|}
\hline $\begin{array}{l}\text { Gradient } \\
\text { No. }\end{array}$ & 2 & 3 & 4 & 5 & 6 & 7 & 8 & 9 & 10 \\
\hline $\begin{array}{l}\text { Mean } \\
\text { Range } \\
\text { S. D. }\end{array}$ & $\begin{array}{c}2.64 \\
1.3-6.6 \\
1.20\end{array}$ & $\begin{array}{c}25.93 \\
14.5-35.9 \\
6.28\end{array}$ & $\begin{array}{c}4.63 \\
2.6-8.4 \\
1.46\end{array}$ & $\begin{array}{c}32.30 \\
22.6-43.2 \\
6.48\end{array}$ & $\begin{array}{c}12.68 \\
7.8-23.0 \\
3.68\end{array}$ & $\begin{array}{c}10.10 \\
6.2-16.3 \\
2.70\end{array}$ & $\begin{array}{c}6.02 \\
2.9-9.8 \\
1.83\end{array}$ & $\begin{array}{l}5.69 \\
3.3-9.6 \\
2.05\end{array}$ & $\begin{array}{c}17.46 \dagger \\
2.8-47.6 \\
13.23\end{array}$ \\
\hline
\end{tabular}

* Data from patterns for 11 individual and three pooled specimens.

$\dagger$ Per cent of total pattern. Figures for gradients 2 through 9 represent per cent of total, exclusive of gradient 10 . 


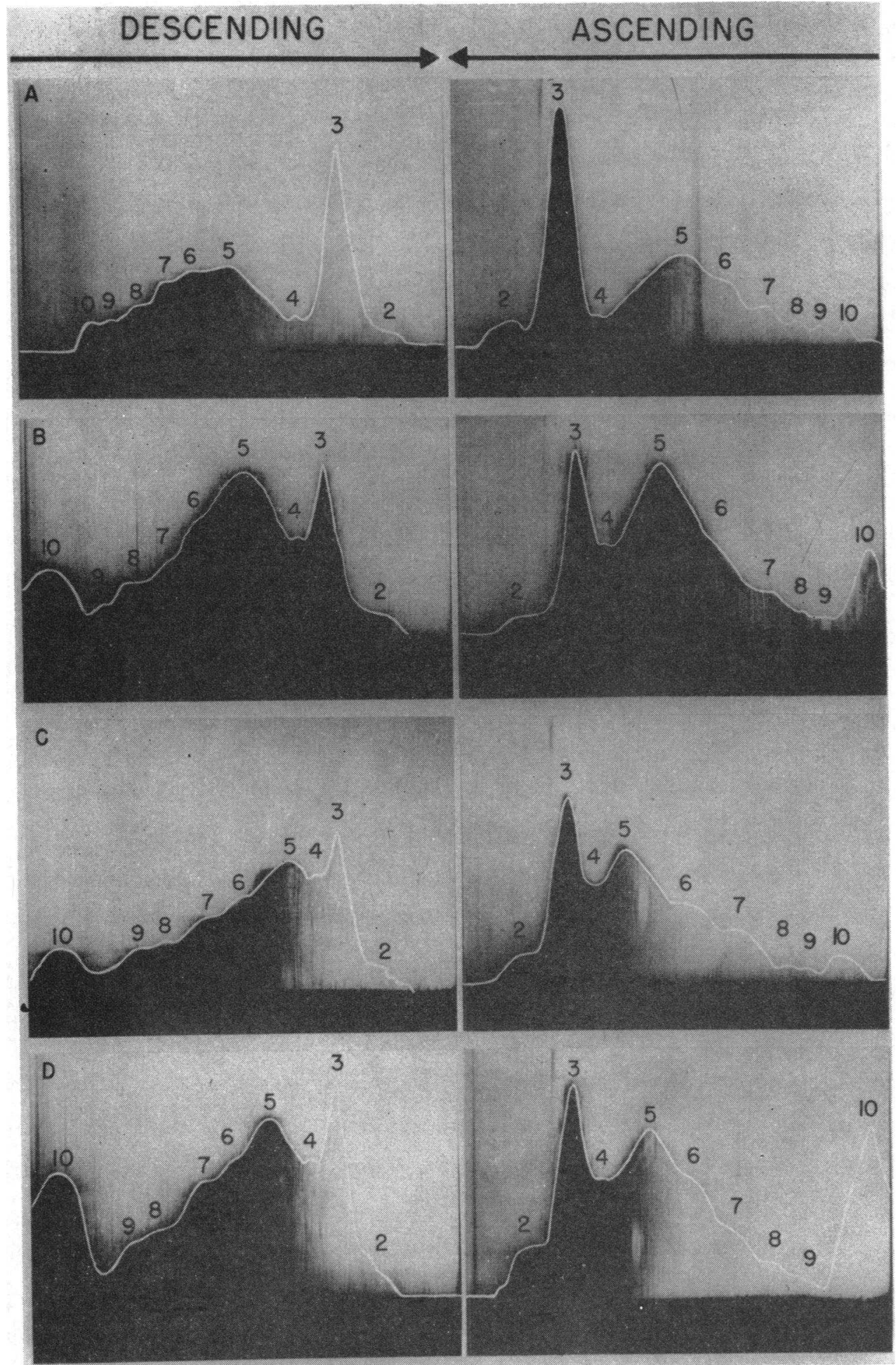

Fig. 4. Concentration Gradients of Total RS-1 Solids from 72 Hour Urine Specimens From Each of Four Subjects

Conditions of electrophoresis as in Figure 3B. (A) and (B) Extreme variations encountered in relative areas of various gradients: (C) and (D) archetypal distribution of various concentration gradients. 
TABLE II

Concentration gradients appearing in serum and in RS-1 fraction of urine TNDS at pH 8.6 *

\begin{tabular}{|c|c|c|c|c|c|c|c|c|c|c|c|c|c|}
\hline \multirow[b]{2}{*}{$\begin{array}{l}\text { Normal } \\
\text { Serum } \\
\text { Normal } \\
\text { Urine } \\
\text { RS -I }\end{array}$} & \multirow[b]{2}{*}{$\begin{array}{c}\text { Component } \\
\mu \text { mean } \\
\pm \text { s.d. } \\
\text { Component } \\
\mu \text { mean } \\
\pm \text { s.d. }\end{array}$} & \multicolumn{12}{|c|}{ Descending toword Anode; Negotive Mobility $-\mu \times 10^{-5} \mathrm{~cm}^{2} /$ volt sec. } \\
\hline & & $\begin{array}{l}\text { (1) } \\
10.24 \\
\pm 0.14\end{array}$ & & $\begin{array}{c}2 \\
7.79 \\
\pm 0.13\end{array}$ & $\begin{array}{c}\text { (1) } \\
\text { Albumin } \\
6.64 \\
\pm 0.14 \\
\text { (3) } \\
6.76 \\
\pm 0.12\end{array}$ & $\begin{array}{c}4 \\
6.06 \\
\pm 0.17\end{array}$ & $\begin{array}{l}2(2) \\
\alpha-1 \\
5.45 \\
\pm 0.17\end{array}$ & $\begin{array}{c}5 \\
4.88 \\
\pm 0.36\end{array}$ & $\begin{array}{c}\text { (3) } \\
\alpha-2 \\
4.34 \\
\pm 0.24 \\
6 \\
4.02 \\
\pm 0.43\end{array}$ & $\begin{array}{c}\text { (4) } \\
\text { 3 } \\
3.22 \\
\pm 0.22 \\
7 \\
3.31 \\
\pm 0.32\end{array}$ & $\begin{array}{c}\text { (5) } \\
\gamma-1 \\
2.42 \\
\pm 0.24 \\
8 \\
2.41 \\
\pm 0.24\end{array}$ & $\begin{array}{c}6 \\
.2-2 \\
1.55 \\
\pm 0.23 \\
99 \\
1.72 \\
\pm 0.24\end{array}$ & $\begin{array}{c}(7) \\
\epsilon \\
\text { Buffer- } \\
\text { protein } \\
\text { gradient } \\
\text { (1) } \\
\text { Immobile } \\
\text { Componert } \\
\epsilon \\
\epsilon\end{array}$ \\
\hline \multicolumn{14}{|c|}{ COHN FRACTIONS } \\
\hline$R S-I A$ & $\begin{array}{c}\text { Component } \\
\mu \text { mean } \\
\pm \text { s.d. }\end{array}$ & & & & & & & Troce & Trace & & $\begin{array}{c}\text { (1) } \\
2.38 \\
\pm 0.20\end{array}$ & $\begin{array}{l}(2) \\
1.61 \\
\pm 0.21\end{array}$ & \\
\hline$R S-1 B$ & $\begin{array}{c}\text { Component } \\
\mu \text { mean } \\
\pm \text { s.d. }\end{array}$ & Troce & & & $\begin{array}{l}\text { (1) } \\
6.76 \\
\pm 0.11\end{array}$ & & $\begin{array}{c}\text { (2) } \\
5.64 \\
\pm 0.26\end{array}$ & $\begin{array}{c}3 \\
4.85 \\
\pm 0.38\end{array}$ & & $\begin{array}{l}4 \\
3.10 \\
\pm 0.21\end{array}$ & & & \\
\hline$R S-I C$ & $\begin{array}{c}\text { Component } \\
\mu \text { mean } \\
\pm \text { s.d. }\end{array}$ & $\begin{array}{l}\text { (1) } \\
10.40 \\
\pm 0.16\end{array}$ & $\begin{array}{l}\text { (2) } \\
8.68 \\
\pm 0.20\end{array}$ & $\begin{array}{l}\text { (3) } \\
7.39 \\
\pm 0.14\end{array}$ & $\begin{array}{c}\text { (4) } \\
6.83 \\
\text { [Troce] }\end{array}$ & $\begin{array}{c}5 \\
6.25 \\
\pm 0.20\end{array}$ & $\begin{array}{c}6 \\
5.68 \\
\pm 0.28\end{array}$ & & $\begin{array}{c}7 \\
4.52 \\
\pm 0.46\end{array}$ & $\begin{array}{c}8 \\
3.24 \\
\pm 0.29\end{array}$ & & & $\begin{array}{c}9 \\
\text { Immobile } \\
\text { component } \\
\epsilon\end{array}$ \\
\hline
\end{tabular}

* Moving boundary electrophoresis: veronal buffer, $\mathrm{pH} 8.6,0.1 \mathrm{M}$; electropotential 5.6 volt/cm.; time 14,400 seconds. The sum of planimeter units (area) of blocked components accounts for more than 95 per cent of the recovered portion of each fraction. Gradients of each fraction are numbered in order of decreasing mobility toward anode.

only a little slower, although considerable trailing makes such interpretation rather ambiguous. Whether these represent the gradients 1 and 2 of RS-1 is unknown. However, traces of these components appeared in both RS-1B and RS-1C with the greater concentration of both appearing in RS-1B. The mobilities on paper relative to albumin were consistent with RS-1 gradients 1 and 2.

RS- 1 concentration gradient 3 had the same mobility as serum albumin at $\mathrm{pH} 8.6$ and 4.5. It also responded to the Cohn Method of fractionation by appearing predominantly in RS-1B (Cohn Fractions IV and V).
RS-1 concentration gradient 4 appeared in good concentration in fraction RS-1C as gradient 5 . This gradient may be present in such small concentration in human plasma that it was obscured by the albumin gradient.

The RS- 1 concentration gradients 5 and 6 were not only the most variable in relative concentration but also in electrophoretic mobility. In a previous report the mobility of component 5 was found to have a mean value of $-4.81 \times 10^{-5}$ $\mathrm{cm}^{2}$ per volt second, as compared with the present determination of $-4.88 \times 10^{-5}$, and component 6 was found to have a mean value of -3.92 $\times 10^{-5}$, as compared with $-4.02 \times 10^{-5}$ for the

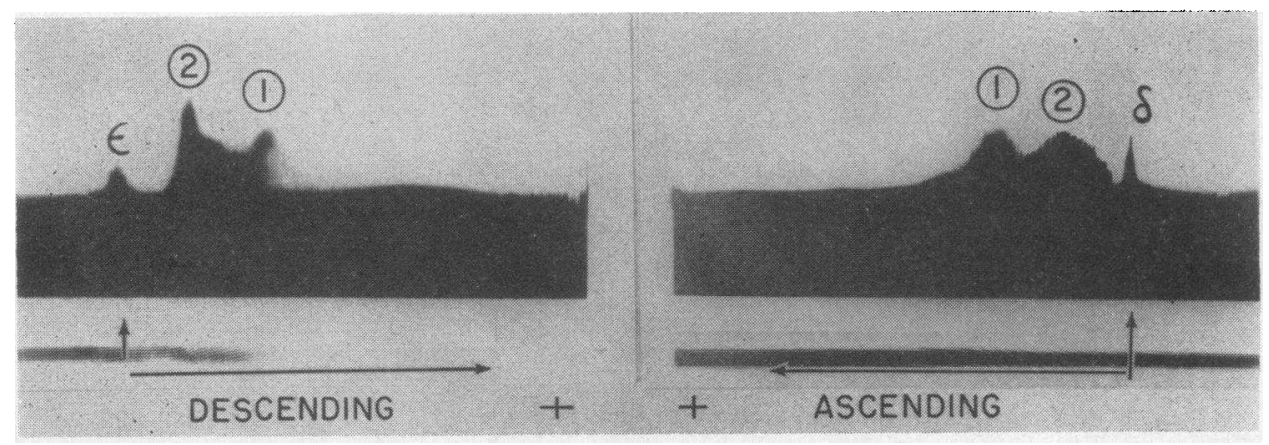

Fig. 5. Concentration Gradients of Subfraction RS-1A (Pool 14, Figure 3) Conditions of electrophoresis as in Figure 3B. 


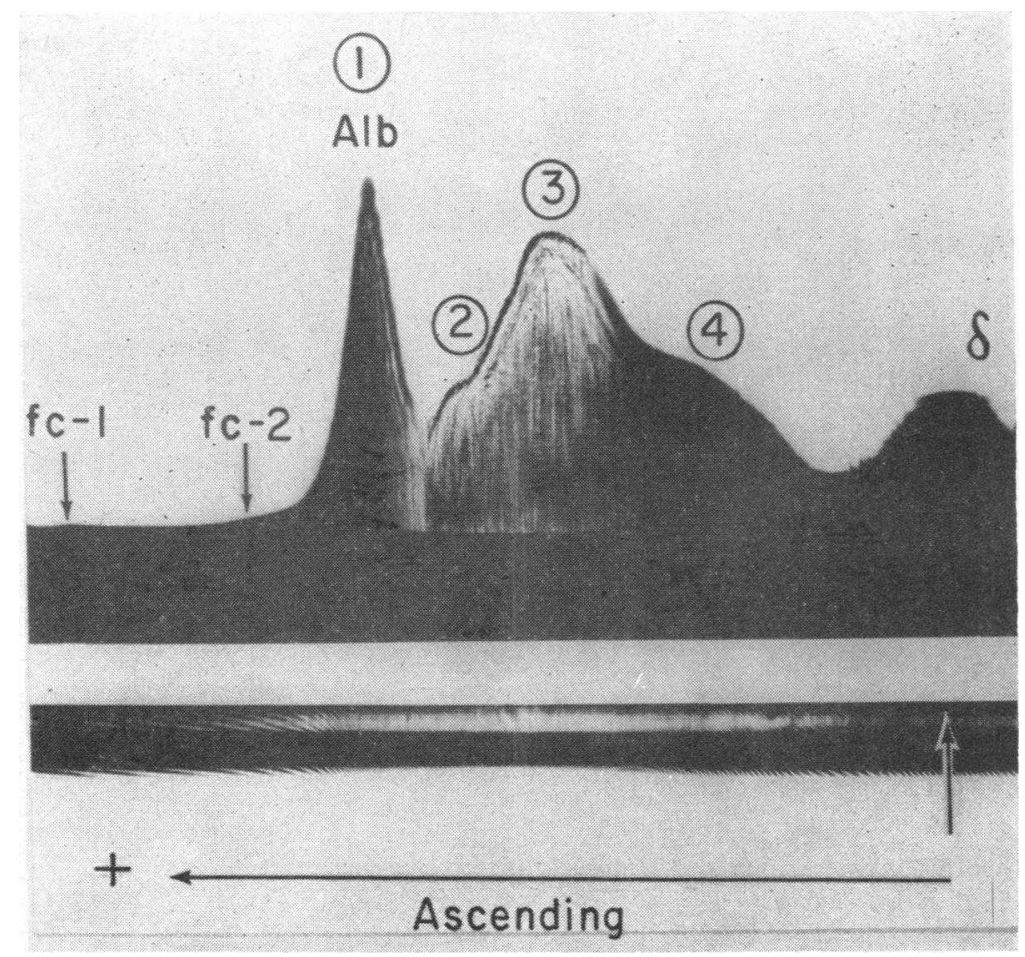

Fig. 6. Concentration Gradients of Subfraction RS-1B (Pool 14, Figure 3)

Conditions of electrophoresis as in Figure 3B. Gradients fc-1 and fc-2 are too small to be measured planimetrically.

present study (6). Component 5 thus has a mobility intermediate between serum alpha-1 and alpha-2. A gradient of mobility similar to RS-1 gradient 5 appeared in RS-1B as component 3 . A gradient of mobility consistent with serum alpha-1 appeared in both RS-1B (gradient 2) and in RS-1C (gradient 6). These gradients of alpha-1 mobility may have been obscured in RS-1 by the large gradient 5 , or their mobility may have been altered by other components of the various fractions so that they appeared as gradient 5 in RS-1.

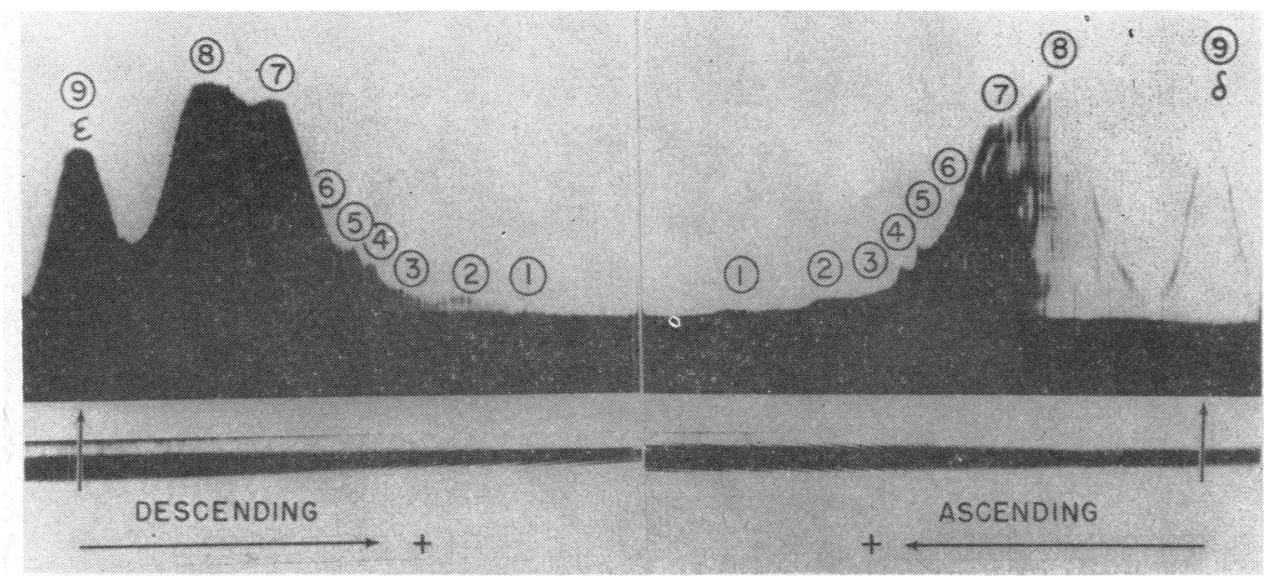

Fig. 7. Concentration Gradients of Subfraction RS-1C (Pool 14, Figure 3) Conditions of electrophoresis as in Figure 3B. 


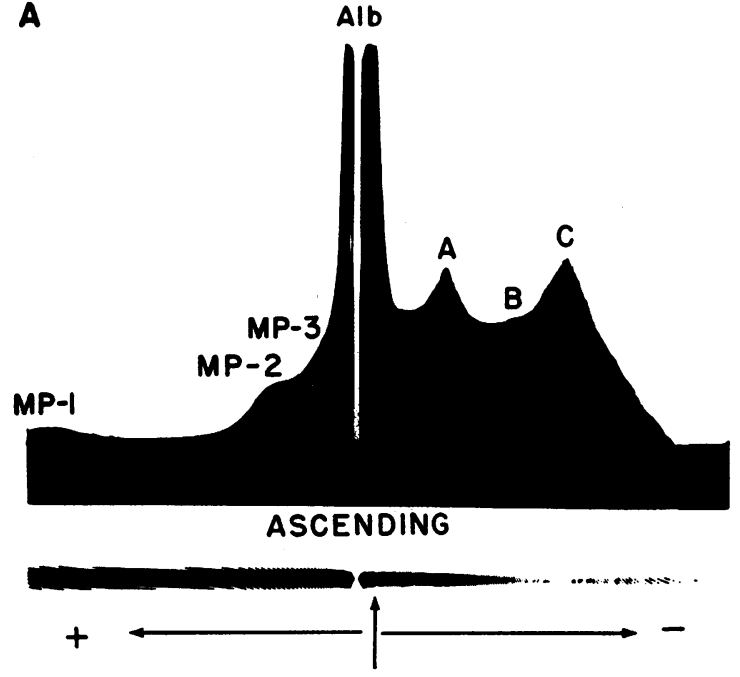

B

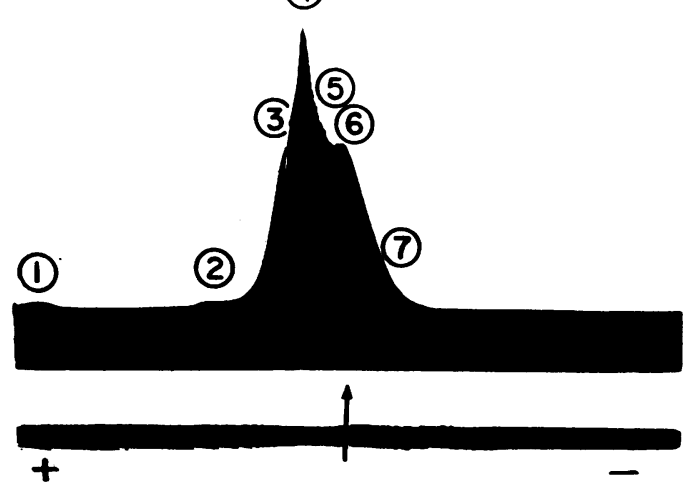

Fig. 8. Electrophoretic Concentration Gradients Following Separation in Acetic Acid-Acetate BUFFer

Ionic strength $0.1, \mathrm{pH} 4.5$, at $1^{\circ} \mathrm{C}$., under a potential gradient of 6.6 volt $/ \mathrm{cm}$., after migration for 14,400 seconds. (A) Normal human serum; (B) pooled total RS-1 solids (Pool 14, Figure 3).

RS-1 gradient 6 had a mobility consistent with serum alpha-2 globulins and appears in the RS-1C (Cohn VI) fraction as gradient 7. Cohn Fraction VI contains serum alpha-2 protein.

RS-1 gradient 7 had a mobility consistent with that of serum beta- 1 and appeared as gradient 4 in RS-1B and as gradient 8 in RS-1C. Fraction RS-1B corresponded to Cohn Fractions IV and $\mathrm{V}$, which contain the serum beta-1 metal-combining protein; fraction RS-1C corresponded to Cohn Fraction VI, which contains serum beta-1 protein. RS-1 gradient 8 corresponded in mobility to serum gamma-1 (plasma phi) and RS-1 gradient 9 to serum gamma-2. Both of these gradients appeared as the principal constituents of RS-1A. RS-1A is comparable to Cohn Fractions I, II and III, which contain gamma globulin and fibrinogen.

RS-1 gradient 10 was a very large stationary boundary, which Rigas and Heller (5) recognized as the "polysaccharide plus epsilon gradient." This large gradient appeared in the RS-1C fraction of urinary proteins. No such substance has been recognized in plasma or in Cohn Fraction $\mathrm{VI}$, which is comparable with RS-1C.

\section{Acetate buffer, $p H 4.5$}

Mehl, Humphrey and Winzler (7) have demonstrated that normal human serum contains three components which retain a net negative charge and have negative mobilities greater than albumin at $\mathrm{pH} 4.5$. These substances have been labeled as mucoproteins MP-1 (orosomucoid), MP-2 and MP-3. Albumin retains a small net negative charge and migrates toward the anode. The remainder of the serum proteins have a net positive charge and appear as three concentration gradients, A, B and C, designated in order of increasing mobility toward the cathode (Figure 8A).

Table III presents a comparison of the mobilities of various concentration gradients in normal serum and in the RS-1 urinary proteins. The mobilities of the serum mucoproteins have been reported to be slightly different when determined on isolated mucoprotein (7) than on mucoprotein in the presence of serum proteins (8).

The total RS-1 fraction was found to contain six distinct gradients with net negative charges at $\mathrm{pH} 4.5$ (Figure 8B). Only a small gradient with mobility comparable to serum component A (RS-1 gradient 7) was found to have a mobility toward the cathode. By planimetry this gradient accounted for approximately 5 per cent of the total RS-1. This component of net positive charge appeared unchanged in fraction RS-1B, as gradient 4 (Figure 9).

Gradient 1 of RS-1 had a mobility much greater than any yet identified in whole serum and appears unchanged as gradient 2 in fraction RS-1C (Figure 10). Gradients 1 and 3 of RS-1C were not identified in the total RS-1, but were consistently present in RS-1C. 
TABLE III

Concentration gradients appearing in scrum and in $R S-1$ fraction of urine TNDS at pH 4.5 *

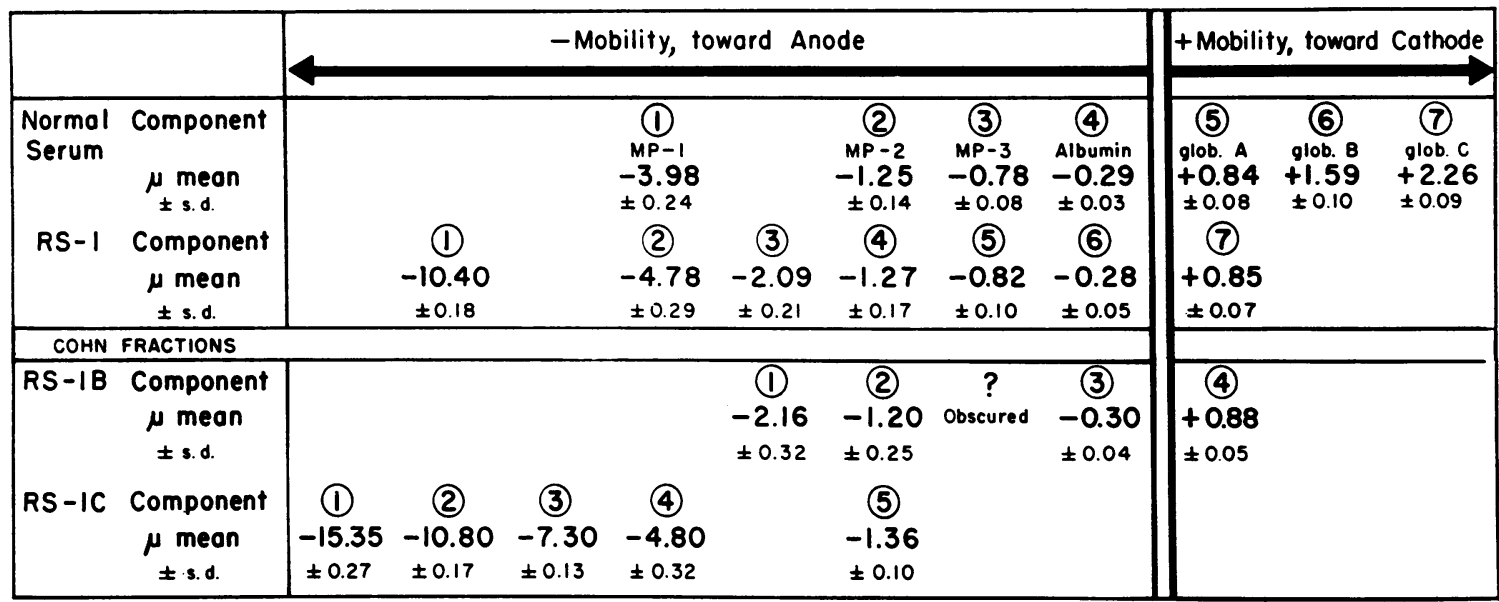

* Moving boundary electrophoresis: acetate buffer, $\mathrm{pH} 4.5,0.1 \mathrm{M}$; electropotential 6.6 volt/cm.; time 14,400 seconds. Mobility expressed as - or $+\mu \times 10^{-5} \mathrm{~cm}^{2}$ per volt second. Gradients of each fraction are numbered in order of decreasing mobility toward anode. S.D. = standard deviation of determination from 11 subjects for RS-1, three or more for each fraction.

Gradient 2 of RS-1 was equivalent in mobility to serum MP-1. Mehl, Golden and Winzler reported a mobility of $-4.2 \times 10^{-5}$ for this component in combination with serum proteins (8), which is in good agreement with the value he obtained for isolated mucoprotein MP-1. This material appeared unchanged as gradient 4 in fraction RS-1C.

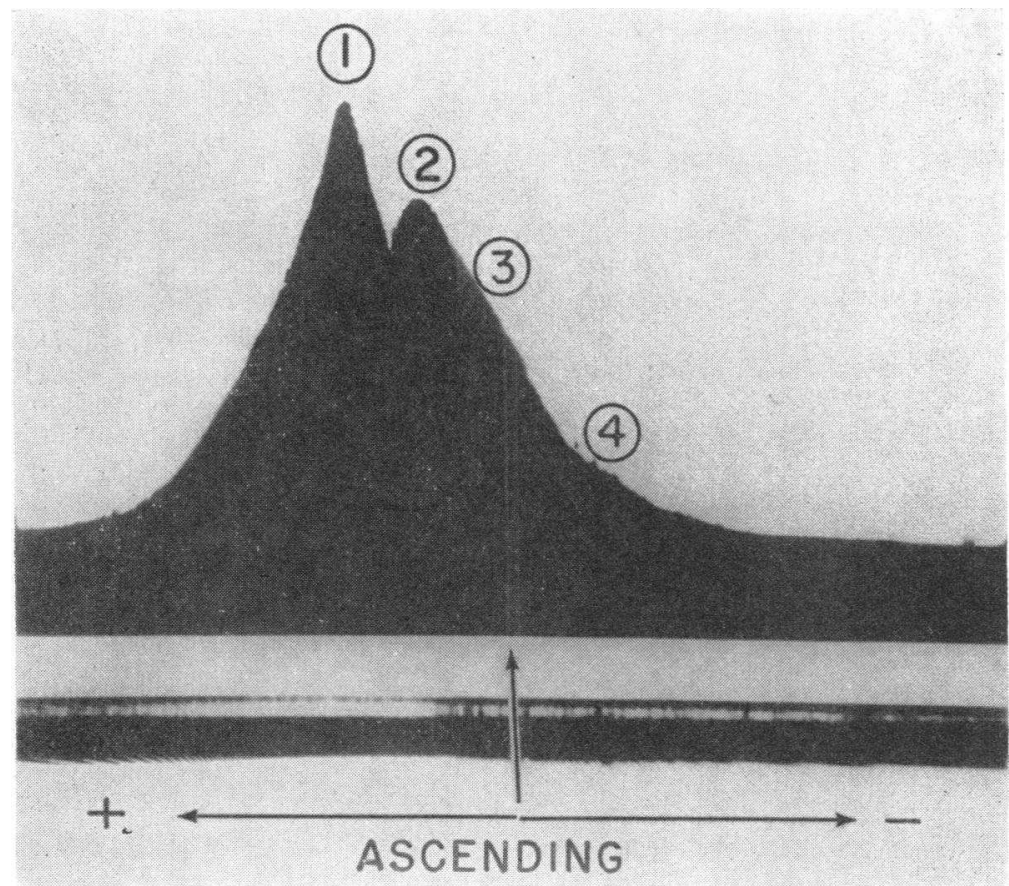

Fig. 9. Concentration Gradients of Subfraction RS-1B (Pool 14, FigURE 3)

Conditions of electrophoresis as in Figure 8B. 


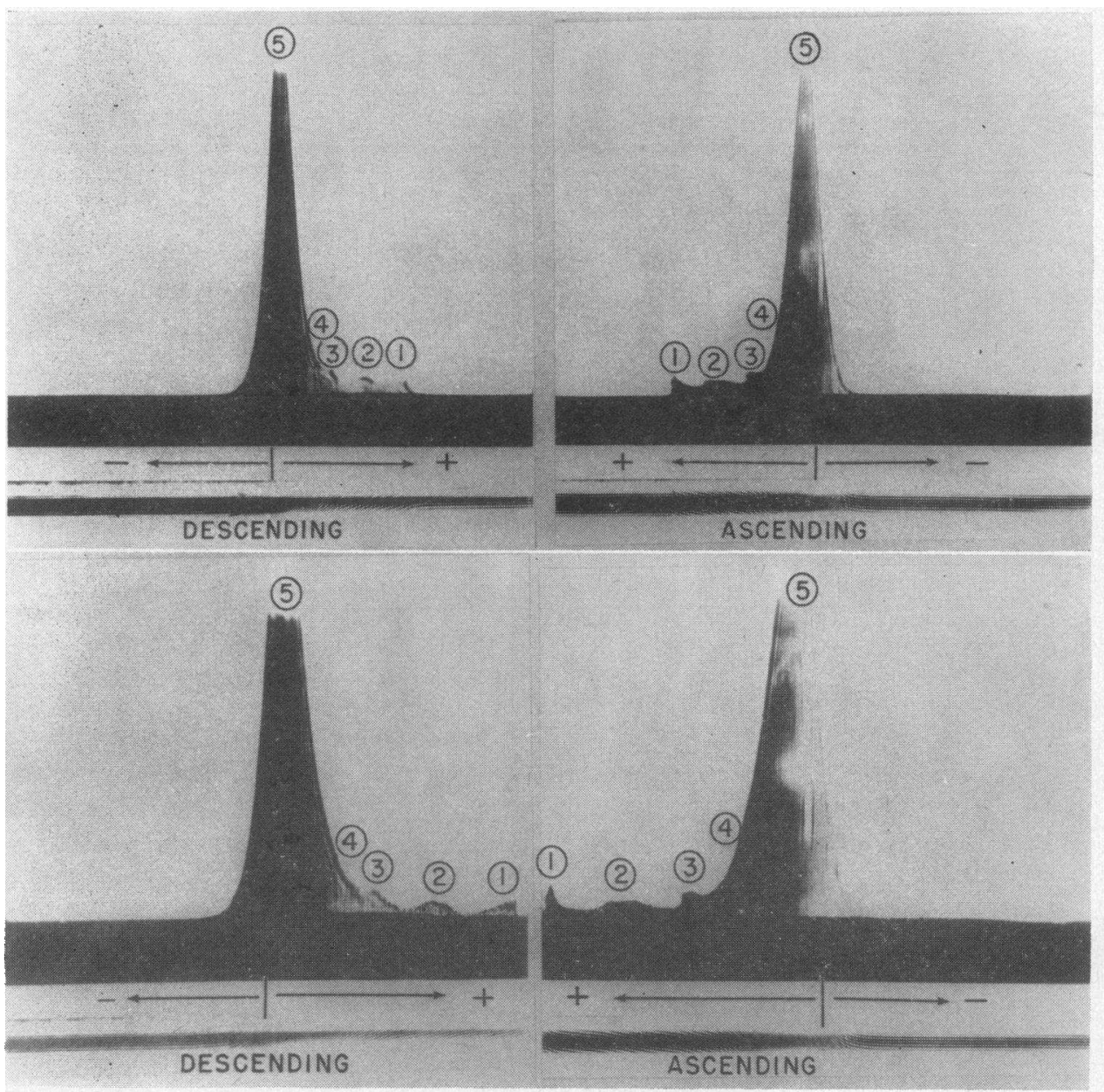

Fig. 10. Concentration Gradients of Subraction RS-1C (Pool 14, Figure 3)

Separation in acetate buffer, $\mathrm{pH} 4.5$, ionic strength 0.1 , at $1^{\circ} \mathrm{C}$., under a potential gradient of 2.6 volt $/ \mathrm{cm}$. (A) After migration for 5,520 seconds; (B) after migration for 9,960 seconds.

Gradient 3 of RS-1 had a mobility consistent with isolated serum MP-2, which Mehl and coworkers reported as -2.4 to $-2.8 \times 10^{-5}(7)$. This gradient appeared unchanged in fraction RS-1B as gradient 1 .

Gradient 4 of RS-1 had a mobility more consistent with serum MP-2 as determined in the presence of serum proteins (8). Gradients of corresponding mobility appeared in the RS-1B as gradient 2 and in $\mathrm{RS}-1 \mathrm{C}$ as gradient 5 . By planimetry, gradient 5 accounts for 74 per cent of fraction RS-1C, a value comparable to the combined area of gradients $5,7,8$ and 9 of this fraction at $\mathrm{pH}$ 8.6. The gradient 5 of RS-1C at $\mathrm{pH} 4.5$ is thus of much greater concentration than the total MP-2 of RS-1 even when RS-1 gradients 3 and 4 are combined.
Gradient 5 of RS-1 was comparable to serum MP-3 in mobility; Mehl, Humphrey and Winzler find a value of -0.5 to $-1.2 \times 10^{-5}$ for isolated MP-3 (7). This gradient is absent from the RS-1C fraction and is probably obscured by albumin and gradient 2 in the RS-1B fractions.

RS-1 component 6 is considered to correspond to serum albumin and appeared in the RS-1B fraction at $\mathrm{pH} 4.5$ and 8.6.

The precipitates which appeared in the total RS-1 and the RS-1B fractions on dialysis from $\mathrm{pH} 8.6$ to $\mathrm{pH} 4.5$, were found to account for approximately 15 to 20 per cent of the total solids. Electrophoresis of these precipitates at $\mathrm{pH} 8.6$ revealed the presence of all concentration gradients in approximately the same relative concentration as in the original preparations. It was noted that 
the precipitates from RS-1B contained a slightly lower albumin to globulin ratio than did the $\mathrm{pH}$ 4.5 soluble supernates. Albumin accounted for 15.5 to 16.1 per cent of the area of the supernate RS-1B and 12.8 to 14.1 per cent of the precipitate of RS-1B. This difference was due largely to a slight increase of gradients 2 and 3 (Figure 6) in the precipitates as compared with the supernates. The separation of solids during equilibrium dialysis to $\mathrm{pH} 4.5$ is therefore considered to represent a coprecipitation involving all components of the solids in essentially the same ratio as their concentration in the solution. This remarkable behavior of such diverse proteins with respect to solubility change with variation in $\mathrm{pH}$ was also observed by Mehl and Golden (9). Although the precipitate which they obtained from a similar treatment of serum was proportionately less than that which we obtained with urine proteins, they were satisfied that no major portion of one component was being removed in the precipitate.

\section{DISCUSSION}

Previously reported studies of fraction R-1 of urinary TNDS (10) and studies of fraction UF-O now being prepared for publication have convinced us that neither of these fractions contains detectable quantities of the protein components recognizable by conventional boundary electrophoresis of plasma. Any such serum protein components which escape, or are secreted, into the urine must therefore appear in the RS- 1 fraction of TNDS. This precludes neither the possibility that all or part of the UF-O (total ultrafiltrable) fraction is derived from the blood plasma nor the possibility that some components of RS-1 originate from sources other than plasma (e.g., genital, urinary or nephrogenic epithelial secretions).

The normal human serum contains approximately $121 \mathrm{mg}$. per $100 \mathrm{ml}$. of protein bound hexose, $83 \mathrm{mg}$. per $100 \mathrm{ml}$. of hexosamine, 8.9 $\mathrm{mg}$. per $100 \mathrm{ml}$. of methylpentose and 60 to $66 \mathrm{mg}$. per $100 \mathrm{ml}$. of sialic acid (11). The majority of these are constituents of mucosubstances and both the analytical (2) and the above electrophoretic data indicate that the bulk of the RS-1 fraction of urine is composed of such mucosubstances. All of the principal fractions of plasma proteins ex- cept $\mathrm{V}$ obtained by the Cohn fractionation technique have been demonstrated to contain mucosubstances $(12,13)$. Of those concentration gradients commonly recognized by electrophoresis of blood plasma at $\mathrm{pH}$ 8.6, all have been demonstrated to contain mucosubstances (14). Albumin has been obtained in a carbohydrate-free form but the difficulty in achieving this suggests that mucosubstances may be closely associated with albumin in the electrophoretic spectrum. Many of the mucosubstances have been isolated in relatively pure form and the following have received considerable attention in recent years:

Orosomucoid (alpha-1 mucoprotein, MP-1) has an isolectric point of approximately 2.7 (11, 15, 16). Alpha-2 mucoproteins include at least three electrophoretically homogenous components, all with isoelectric points of 3.7 to 4.4 (7, 17). Haptoglobulin has an electrophoretic mobility similar to the alpha-2 globulins and has been recovered from human serum and nephrotic urine (14). Both pituitary and chorionic gonadotropins have mobilities in the range of the alpha globulins and isoelectric points of near 3.2 (18). Thyroxin binding protein of human serum is electrophoretically a component of the alpha-2 globulins at $\mathrm{pH} 8.6$ and retains a net negative charge at $\mathrm{pH} 4.5$ (19). Prothrombin contains bound hexose, hexosamine and sialic acid (14) and migrates with the alpha globulins at $\mathrm{pH}$ 8.6. Plasma cholinesterase is considered to be a glycoprotein with electrophoretic mobility similar to the alpha-2 globulins (20). Beta-1-metal-combining protein (siderophilin) was crystallized (21) and has an isoelectric point near 5.8. Both the gamma-1 (19 S) and gamma (7 S) globulins were found to contain hexose, fucose, hexosamine and sialic acid (22).

There are thus ample mucosubstances in normal plasma to account for the "globulin" components of RS-1 urinary proteins at $\mathrm{pH}$ 8.6. Present knowledge does not permit an unequivocal identification of the various mucosubstances of RS-1 with those of plasma. It has been suggested that the reversal of the albumin/globulin ratio of urinary proteins is due to passage of small quantities of serum proteins through the glomeruli with preferential tubular reabsorption of albumin (23). The present studies indicate that all serum proteins which pass the normal nephron have very 
low isoelectric points, all but 5 per cent retaining a net negative charge at $\mathrm{pH}$ 4.5. The observation that the relative concentration of mucosubstances in the electrophoretic gradients of serum are proportionately the same as in gradients of corresponding mobility in urinary RS-1 suggests that these molecules pass the glomerular membrane in ratios approximating their plasma concentration. Whether tubular reabsorption plays any significant part in the final urinary concentration or composition remains unknown. The absence of the major plasma globulins with isoelectric points more than 4.5 suggests that under normal conditions RS-1 components appear in the urine as a result of selective glomerular filtration, passage through the membrane being related not alone to molecular size and shape but also in some manner to electrical charge or configuration.

\section{SUMMARY}

The RS-1 (nonultrafiltrable and veronal buffer soluble) fraction of urinary proteins has been subjected to electrophoretic analysis at $\mathrm{pH} 8.6$ and 4.5. This fraction contains all of the serum albumin present in urine and thus presumably all serum proteins of molecular size greater than albumin. The minimal molecular weight component in this fraction has not been identified, but the majority of the components are of such size that diffusion is not a problem in conventional boundary electrophoresis of five hours' duration.

Cohn method 10 for fractionation of serum proteins at low temperature in the presence of low concentrations of ethanol and of zinc acetate has been applied to the RS-1 fraction. Three reproducible subfractions were obtained: RS-1A (Cohn I, II and III), RS-1B (Cohn IV and V), and RS-1C (Cohn VI). These fractions have also been analyzed by electrophoresis at $\mathrm{pH} 8.6$ and 4.5.

Essentially all protein components which appear in normal urinary RS-1 solids have isoelectric points below $\mathrm{pH} 4.5$. It is apparent that the majority, if not all, of the RS-1 solids are mucosubstances which have counterparts in the blood plasma.

\section{ACKNOWLEDGMENT}

The authors wish to express their appreciation to Mrs. Phyllis Tilley for technical assistance.

\section{REFERENCES}

1. Boyce, W. H., King, J. S., Jr., Little, J. M., and Artom, C. Total nondialyzable solids (TNDS) in human urine. II. A method for reproducible fractionation. J. clin. Invest. 1958, 37, 1658.

2. King, J. S., Jr., Little, J. M., Boyce, W. H., and Artom, C. Total nondialyzable solids (TNDS) in human urine. III. A method for subfractionation of RS-1 solids. J. clin. Invest. 1959, 38, 1520.

3. Longsworth, L. G., and MacInnes, D. A. An electrophoretic study of nephrotic sera and urine. J. exp. Med. 1950, 71, 77.

4. Dole, V. P. The electrophoretic patterns of normal plasma. J. clin. Invest. 1944, 23, 708.

5. Rigas, D. A., and Heller, C. G. The amount and nature of urinary proteins in normal human subjects. J. clin. Invest. 1951, 30, 853.

6. Boyce, W. H., Garvey, F. K., and Norfleet, C. M., Jr. Proteins and other biocolloids of urine in health and in calculous disease. I. Electrophoretic studies at $\mathrm{pH} 4.5$ and 8.6 of those components soluble in molar sodium chloride. J. clin. Invest. 1954, 33, 1287.

7. Mehl, J. W., Humphrey, J., and Winzler, R. J. Mucoproteins of human plasma. III. Electrophoretic studies of mucoproteins from perchloric acid filtrates of plasma. Proc. Soc. exp. Biol. (N. Y.) 1949, 72, 106.

8. Mehl, J. W., Golden, F., and Winzler, R. J. Mucoproteins of human plasma. IV. Electrophoretic demonstration of mucoproteins in serum at $\mathrm{pH}$ 4.5. Proc. Soc. exp. Biol. (N. Y.) 1949, 72, 110.

9. Mehl, J. W., and Golden, F. Electrophoretic studies of human serum at $\mathrm{pH} 4.5$. J. clin. Invest. 1950, 29, 1214.

10. Boyce, W. H., and Swanson, M. Biocolloids of urine in health and in calculous disease. II. Electrophoretic and biochemical studies of a mucoprotein insoluble in molar sodium chloride. J. clin. Invest. 1955, 34, 1581.

11. Winzler, R. J. Determination of serum glycoproteins in Methods of Biochemical Analysis, D. Glick, Ed. New York, Interscience Publishers, 1955, vol. 2, p. 279.

12. Cohn, E. J., Strong, L. E., Hughes, W. L., Jr., Mu1ford, D. J., Ashworth, J. N., Melin, M., and Taylor, H. L. Preparation and properties of serum and plasma proteins. IV. A system for the separation into fractions of the protein and lipoprotein components of biological tissues and fluids. J. Amer. chem. Soc. 1946, 68, 459.

13. Weimer, H. E., Redlich-Moshin, J., Salkin, D., and Boak, R. Distribution of glycoproteins in normal human plasma. Proc. Soc. exp. Biol. (N. Y.) 1954, 87, 102.

14. Bettelheim-Jevons, F. R. Protein-carbohydrate complexes in Advances in Protein Chemistry, C. B. Anfinsen, Jr., K. Bailey, M. L. Anson and J. T. 
Edsall, Eds. New York, Academic Press Inc., 1958 , vol. 13 , p. 35 .

15. Weimer, H. E., Mehl, J. W., and Winzler, R. J. Studies on the mucoproteins of human plasma. V. Isolation and characterization of a homogeneous mucoprotein. J. biol. Chem. 1950, 185, 561.

16. Schmid, K. Preparation and properties of serum and plasma proteins. XXIX. Separation from human plasma of polysaccharides, peptides and proteins of low molecular weight. Crystallization of an acid glycoprotein. J. Amer. chem. Soc. 1953, 75, 60.

17. Schmid, K. Isolation of a group of $\alpha_{2}$-glycoproteins from human plasma. J. Amer. chem. Soc. 1955, 77, 742.

18. Li, C. H. The chemistry of gonadotropic hormones in Vitamins and Hormones, R. S. Harris and K. V. Thimann, Eds. New York, Academic Press Inc., 1949, vol. 7, p. 223.
19. Robbins, J., Petermann, M. L., and Rall, J. E. Electrophoresis of the serum thyroxine-binding protein at pH 4.5 (abstract). Fed. Proc. 1954, 13, 280.

20. Surgenor, D. M., and Ellis, D. Preparation and properties of serum and plasma proteins. Plasma cholinesterase. J. Amer. chem. Soc. 1954, 76, 6049.

21. Koechlin, B. A. Preparation and properties of serum and plasma proteins. XXVIII. The $\beta$-1-metalcombining protein of human plasma. J. Amer. chem. Soc. 1952, 74, 2649.

22. Müller-Eberhard, H. J., Kunkel, H. G., and Franklin, E. C. Two types of $\gamma$-globulin differing in carbohydrate content. Proc. Soc. exp. Biol. (N. Y.) 1956, 93, 146.

23. Gregoire, F., Malmendier, C., and Lambert, P. P. The mechanism of proteinuria, and a study of the effects of hormonal therapy in the nephrotic syndrome. Amer. J. Med. 1958, 25, 516. 